\title{
ACTIVATION OF LOCAL COMMUNITIES FOR DEVELOPMENT OF RURAL AREAS
}

\author{
Julia Doitchinova ${ }^{1}$, Zornitsa Stoyanova ${ }^{2}$
}

\begin{abstract}
Summary
The article examines the main problems encountered during the development of area-based partnerships in rural Bulgaria. These partnerships were created to enhance endogenous development in rural areas and have been rapidly adopted due to the requirement to run the European Union LEADER type program.

Purpose of the article is to assess the practice and the problems of implementation of the LEADER approach in Bulgaria for the first membership program period and to offer recommendations to increase the motivation of local communities for the development and implementation of local development strategies.

Conclusions and recommendations for improving the practice of implementation of the Leader approach is based on the results of the survey and analysis of the documents of local action groups and the Program for Rural Development, realized within a research project by a team from the University of National and World Economy Sofia.
\end{abstract}

Key words: LEADER, local action group (LAG), rural development, rural development program.

JEL: $Q 16, R 58$.

\section{Introduction}

The Rural Development Program (RDP) funded by the EU support a wide range of activities. Thereby an integrated approach to rural development seems to contribute more to this highly complex task than sectorial approaches. Thus rural development must deal with multifunctionality (Gallent et al., 2008) as a comprehensive territorial development approach that is based on the strengths, weaknesses, opportunities for, and threats to, a region (Terluin, 2003). The LEADER approach is one part of this, and employs a bottom-up, participatory approach in which stakeholders from different

1 Julia Doitchinova, D.Sc. (Econ.), Full Professor, University of National and World Economy, Student city, 1700 Sofia, Bulgaria, Phone: +359 281953 84, E-mail: juliadoj@abv.bg

2 Zornitsa Stoyanova, Ph.D., Associated Professor, University of National and World Economy, Student city, 1700 Sofia, Bulgaria, Phone: +359 281954 60, E-mail: zori_stojanowa@yahoo.de 
institutions together form a Local Action Group (LAG) as a kind of a public-private partnership that makes decisions about the financial support for projects.

Unlike previous approaches to regional development, the approach "bottom up" is consensus-oriented, multi-decision levels-based, with dynamic interactivity among a plurality of actors, including civil-society actors such as private partners or environmental organized interests (NGOs), inter-sectoral links and less defined tasks (Kjaer, 2004). Through this it is possible to decentralize significant part of the decisions and according to the specific conditions in each EU Member State and in each region, to reflect the characteristics of the economic development of the territories, culture of the rural population and others (Dargan, Shucksmith, 2008).

The LEADER method is based on the principles of subsidiary and partnership. These two principles underlie the creation of a decision-making entity, a Local Action Group (LAG), appearing as the project manager for the projects carried out by three categories of local stakeholders - self-governments, entrepreneurs, associations (Maurel 2008; Chevalier, Maurel, 2010). LAG as the type of partnership is a system of formalized cooperation, grounded in legally binding arrangements or in formal undertaking of co-operative working relationships and mutually adopted plans among a number of institutions (OECD 1990). Such a definition is convenient due to different legal systems in various countries determining formal legal structures of partnerships and a great variety of functions and targets.

The area-based partnership can define as a voluntary and open coalition of leaders from different public sectors (territorial self-government, NGOs, companies, state institutions, schools etc.), which together prepare and realize practical, long-term activities aimed at local development and the solving of economic, social and ecological problems in a particular territory (Biderman et al., 2004; Doitchinova et al., 2013). Involving local people is one of the pillars of LEADER LAGs and plays a key role to stimulate the development of the territory, not just to administer (Stoyanova, 2011).

Furmankiewicz (2008) has pointed out that the significant feature of new-created partnerships is the occurrences of strong (durable) connections, consensus and long-term decision-making and transparency. The unsuitability of the institutional structures and of the cognitive matrices in relation to the presuppositions of the bottom-up approach may have an inhibiting effect on the reception of the LEADER model. The lack of social capital and more specifically the lack of entrepreneurs, the weak social links, the under-education of the rural population, and the demographic aging process, all serve to put a brake on the involvement of local actors. It is hard for local communities to adjust and to make good use of their skills (Chevalier, Maurel, 2010). These elements help explain the context of the reception of the LEADER model.

The transition in the implementation of the LEADER approach in early 2007 - from Commission to national level posed a number of problems for its implementation mainly in the new EU members. A number of researchers (Gorton et al., 2009) consider the lack of convergence in the socio-economic conditions of rural areas 
in New Member States and established Member States to be an implementation. The explanation, why the CAP does not fit Central and Eastern Europe. For these reasons, any analysis and evaluation of the implementation of LEADER approach and proposals for adapting it to the particularities of rural regions to the respective country can contribute to its successful.

Purpose of the article is to assess the practice and the problems of implementation of the LEADER approach in Bulgaria for the first membership program period and to offer recommendations to increase the motivation of local communities for the development and implementation of local development strategies (LDSs).

\section{Methodological framework}

Findings and conclusions in the paper are based on the results of university research project and an analysis of the publications of the current estimates of the Rural development program (RDP) in Bulgaria. In accordance with EU recommendations, the analysis focuses on the results of impact and procedures for implementation of the RDP, as well as comparisons with other new countries for the last 10 years.

Within the research project in LAG is conducted a survey and in-depth structured interviews with managers and LAG members, mayors and municipal officials as well as civil servants on various levels of government. The questions are pointed to the problems in the implementation of the LEADER approach in Bulgaria. Questions contained in the survey are closed type, as well as for personal evaluation. Open questions were used to obtain additional information about the variety of actors, projects and problems.

In selecting the objects of interest were used the following criteria:

Areas with high activity of the municipalities and civic structures under Axis Leader. These are areas in which the majority of rural LAG are formed during the period until 2009;

$>$ Disadvantaged and other rural areas with natural climatic, terrain and other constraints;

Municipalities with fewer people, united in a common local action group;

Municipalities involved in the preparation of projects for "Leader" implementation;

$>$ Areas with high potential for development due to their spatial location and opportunities for cross-border cooperation.

The choice of objects of study is conducted by using at least two criteria. The majority of the municipalities are eligible for three, even four criteria.

It is studied the approved local development strategies of $66 \%$ of LAGs in Bulgaria and assessed priorities and objectives of funding and problems in their implementation. 


\section{Bulgarian version of the LEADER in comparison with other new EU members}

The second by distribution in the EU „LEADER model” is applied in Bulgaria (Figure 1). Its application is characterized by decentralization in the approval of projects. LAG is responsible for evaluation, selection and approval and the issuance and delivery of the notification of beneficiaries. Payments to beneficiaries are made by the Paying Agency. This model is applied in Portugal, Malta, Belgium (Flanders) and parts of Italy. ${ }^{3}$

Figure 1. European LEADER models

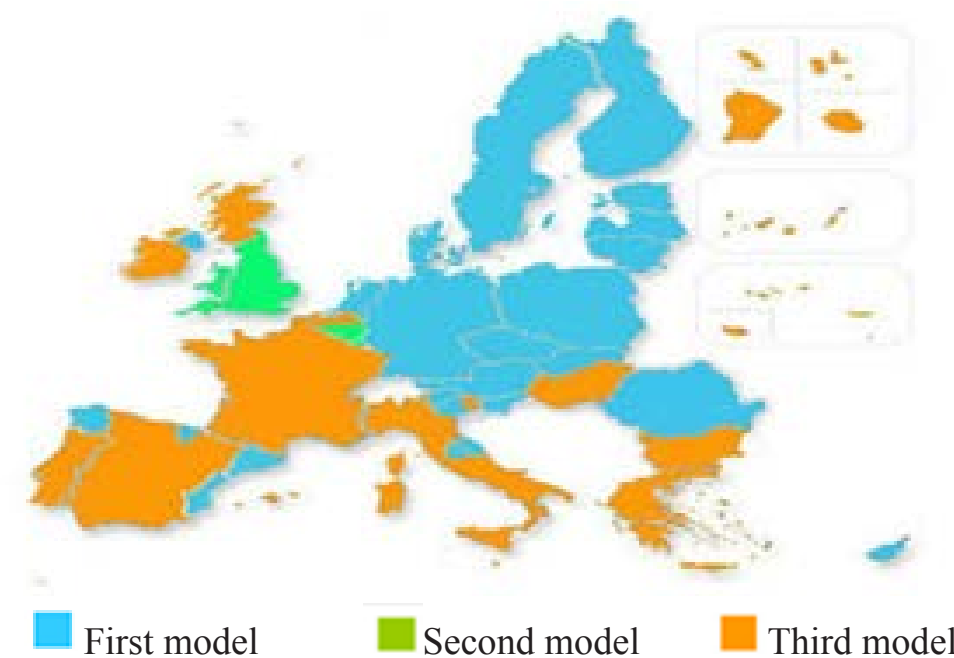

Source: Focus Group 1- Summary of the Extended Report: the Implementation of Leader Approach for publication, December, 2010.

Regardless of the common EU regulation for a minimum percentage of funds under Axis 4 LEADER, the new member states have adopted divergent decisions in their national programs for rural development in 2007. Data show that $33 \%$ received values close to the accepted $2.5 \%$ (Table 1 ).

Table 1. Distribution of EU-12 by share of funds under Axis 4 LEADER of the total amount of funds in national rural development programs

\begin{tabular}{|c|c|c|c|}
\hline Indicator & No. of countries & Structure & Countries \\
\hline up to 3 & 4 & 32.2 & Bulgaria, Slovenia, Slovakia, Latvia \\
\hline $3,1-4$ & 2 & 16.7 & Cyprus, Malta \\
\hline $4.1-5$ & 2 & 16.7 & Romania, Poland \\
\hline $5.1-6$ & 2 & 16.7 & Czech Republic, Hungary \\
\hline over 6 & 2 & 16.7 & Estonia, Lithuania \\
\hline
\end{tabular}

Source: EC, Rural Development in the European Union. Statistical and Economic Information, Report, 2013.

3 Abruzzo, Basilicata, Calabria, Emilia Romagna, Puglia, Sardinia, Sicily, Tuscany, Trento, Campania and others. 
The lowest share of funds under Axis 4 is in Bulgaria (only $2.3 \%$ ). At the same time for activation of local communities and revitalize rural areas countries like Estonia and Lithuania are given respectively 9. 5 and $6.1 \%$. These values are higher than these in the most countries in the EU-15. At EU-27 level, Axis 4 represents $6.3 \%$ of the EAFRD contribution. Denmark and Spain are the Member States which attribute most importance to this bottom-up approach (11\% each).

Analysis of the structure of the measures and funds in LDSs reveal different approaches and strategic decisions of the member states. As a whole it is observed that the priorities are pointed to improving the quality of life in rural areas and diversification of employment (M 413 - Figure 2). The funds for this purpose are in the range of 33.5\% (Malta) to 79.2\% (Slovenia). The only exception is Latvia. There are not such funds in its rural development program for Axis LEADER.

Figure 2. Distribution of funds under Axis $4^{4}$ of the rural development programs in the new Member States for the period 2007-2013

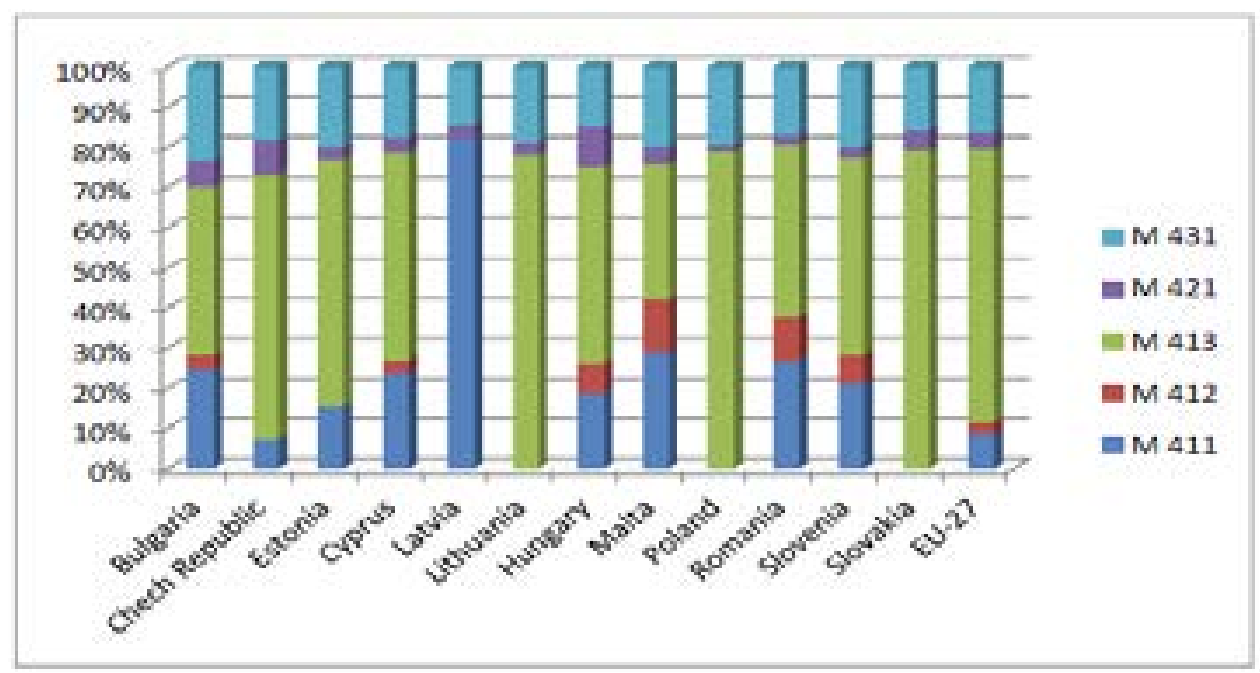

Source: EC, Rural Development in the European Union. Statistical and Economic Information, Report, 2013.

At the same time half of the EU-12 has limited the number of the measures. They have directed the majority of the funds to one of the measures. This is most visible in the distribution of funds under Axis 4 in rural development programs of Latvia, Lithuania, Poland and Slovakia. These countries have treated more than $75 \%$ of the budget for Axis Leader for increasing the competitiveness (Latvia 82.8\% - M411) and improving the quality of life (Slovakia 79.2\%, Poland $78.8 \%$, Lithuania $78 \%$ ). At the same

$4 \quad$ M 411 - Implementing local development strategies. Competitiveness;

M 412 - Implementing local development strategies. Environment/land management;

M 413 - Implementing local development strategies. Quality of life/diversification;

M 421 - Implementing cooperation projects;

M 431 - Running the local action group, acquiring skills and animation the territory.

EP 2014 (61) 3 (661-675) 
time these countries such as Estonia have not provided the funds for the realization of environmental objectives and management of the area (M-412).

In comparison with these countries, it can be concluded that Bulgaria had underestimated the importance of the LEADER approach for rural development and motivation for activation of local communities. Thus it is has limited the process of management decentralization of public funds. At the same time the use of all measures for the implementation of local development strategies is complicated and created difficulties in preparation for the introduction, management and the expected effects of the implementation of the Leader approach.

\section{Evaluation of the LEADER approach implementation}

In the pre accession period (2003-2007) in Bulgaria were made several projects for development of administrative capacity and skills of civil society for the implementation of the LEADER approach. They are funded by the EU and other international organizations and are aimed primarily at small communities and to the backward rural areas with unfavourable conditions.

The actual application of the approach started in 2007 with the preparation of the legal basis for the implementation of various measures. Regardless of the experience gained from the pilot projects and training administration at national level, the first call for preparatory measure 431-2 Running costs, acquisition of skills and animation - potential LAGs was launched only in 2008, and the first contracts for approved projects were signed in July, 2009.

After the end of acceptance of the projects for this measure in 2010 were created 103 LAGs in 25 districts, covering the territory of 158 rural municipalities or $68.3 \%$ of the municipalities designated as rural, $71 \%$ of the rural population and 2,265 million persons or $70.8 \%$ of the rural population. The expectations contained in the Plan for Rural Development are significantly surpassed: " to prepare at least 60 potential local active groups". It shows that in the future LAG could have decisive importance for the development of rural areas and their inhabitants. Furthermore, more than 30 projects haven't been approved, while $10 \%$ of the approved for funding projects have not entered into contracts or their contracts were terminated.

Under Measure 41 "Implementation of local development strategies" and submeasure 431-1 "Running costs, acquisition of skills and animation - selected LAGs" are applied 126 proposals for LDSs. The strategies of 35 LAGs were approved (only $27.8 \%$ ). These LAGs cover 57 municipalities $(24.7 \%$ of the rural municipalities), have a population of 800758 people (less than $25 \%$ of the population in rural areas) and $27.8 \%$ of the rural areas.

Table 2 presents main characteristics of local action groups - average, minimal and maximal values. The number of villages is between 4 and 87 and shows differences in conditions in rural areas. Data show that most villages are in the territories of the local action groups in mountainous and hilly areas of the country. 
Population and territory varies more 6 times. The average population of the territory of a local action group indicates that the majority of areas are with relatively few inhabitants. Even local action group with the largest population reaches only $78 \%$ of the maximum level.

Most of LAGs are located in the territory of one municipality (52\%) and $17 \%$ of LAG - in the territory of three municipalities. Around one third of all LAGs are on the territory of two municipalities.

Table 2. Main characteristics of local action groups

\begin{tabular}{|c|c|c|c|c|}
\hline Index & $\begin{array}{c}\text { No. of } \\
\text { municipalities }\end{array}$ & No. of villages & Population & Area (km²) \\
\hline Average & 1.6 & 31,3 & 23,575 & 737,156 \\
\hline Min & 1 & 4 & 12,128 & 263.96 \\
LAG Kneja & LAG Ardino & LAG Rakovski \\
\hline Max & $\begin{array}{c}3+\text { part of forth } \\
\text { LAG Nord } \\
\text { Stara planina - } \\
\text { Kopren-Midjur }\end{array}$ & LAG Breznik-Trun & $\begin{array}{c}78,636 \\
\text { LAG Belovo- } \\
\text { Septemvri- } \\
\text { Velrigrad }\end{array}$ & $\begin{array}{c}\text { LAG Belovo- } \\
\text { Septemvri- } \\
\text { Velrigrad }\end{array}$ \\
\hline
\end{tabular}

Source: Ministry of Agriculture and food, Bulgaria, Sofia.

Note: Municipality Berkoviza is divided between LAG Nord Stara planina - Kopren-Midjur and LAG Berkoviza - Godech.

Figure 3 presents the total public expenditures which was planned in the LDSs of 32 of the 35 approved strategies.

Figure 3. Total public expenditures of LDSs by axis (in EUR)

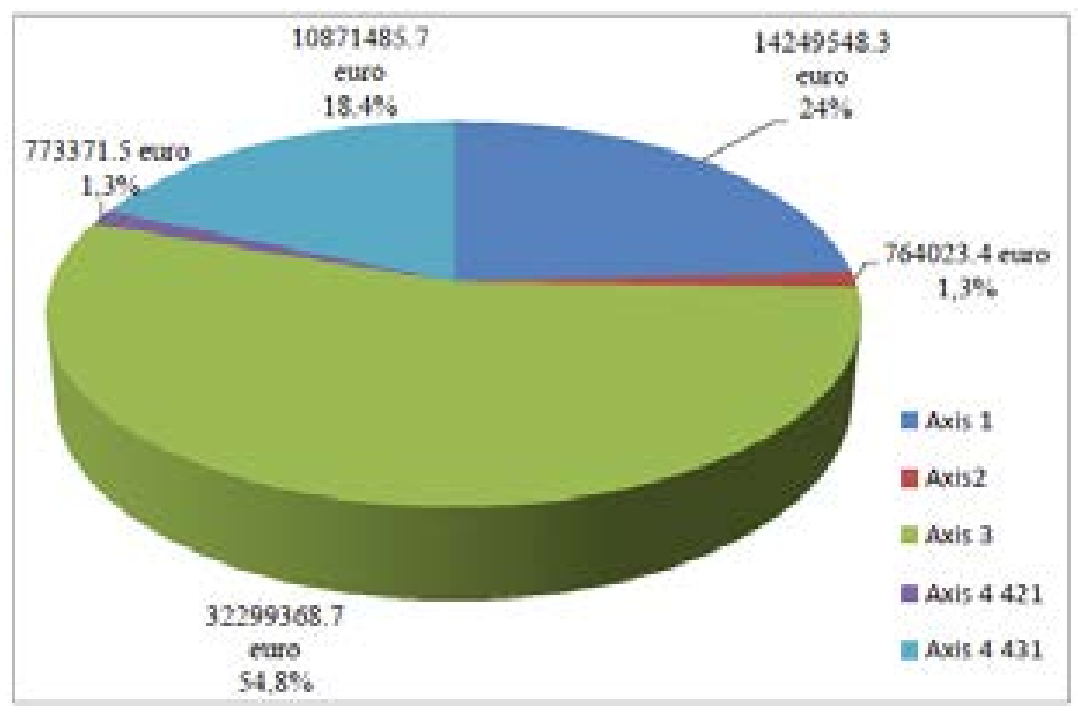

Source: LDSs of 32 approved strategies. 
The planned public expenditure has the highest share of Axis 3 „Quality of life in rural areas and diversification of the rural economy ". The planned funds have an amount of $32,299,368$ euro or $54.8 \%$ of total public expenditures. Second priority has axis 1 "Improving the competitiveness of the agricultural and forestry sector" and the planned public expenditures represents 24\% of the total amount. Axis 2 and Axis 4 have the lowest share, respectively 764,023 and 773,371 euro or $1.3 \%$ of total public expenditure. Overall, the share of funds for Axis 2 ,Improving the environment and nature” is low, only 16 LAGs have provided measures of this axis in their LDSs.

Table 3 presents the indicative allocations to the measures included in the LDSs of 32 of the 35 LAGs. The total public expenditure planned in the strategies ranges from 43,234.6 to $920,6549.8$ euro for the various measures included in the strategies. In the structure of total public contribution for the period of the strategy, the highest share of funding is provided by measure 312 "Support for the creation and development of micro-enterprises" and measure 121 "Modernisation of agricultural holdings", respectively, $15.6 \%$ and $14.9 \%$ and the lowest share is for measure 122 "Improving the economic value of the forests", only $0.1 \%$.

Table 3. Indicative allocation by measures for the period of LDSs

\begin{tabular}{|l|c|c|}
\hline \multicolumn{1}{|c|}{ Measure of LDSs } & $\begin{array}{c}\text { Total public } \\
\text { expenditures, } \\
\text { in EUR }\end{array}$ & $\begin{array}{c}\text { Structure, } \\
\%\end{array}$ \\
\hline 111 Training, information and diffusion of knowledge & $296,286.9$ & 0.5 \\
\hline 121 Modernisation of agricultural holdings & $8,793,613.5$ & 14.9 \\
\hline 122 Improving the economic value of the forests & $43,234.6$ & 0.1 \\
\hline 123 Adding value to agricultural and forestry products & $5,116,413.2$ & 8.7 \\
\hline 223 First afforestation of non-agricultural land & $400,813.2$ & 0.7 \\
\hline 226 Restoring forestry potential and introducing prevention actions & $363,210.2$ & 0.6 \\
\hline 311 Diversification into non-agricultural activities & $4,421,704.7$ & 7.5 \\
\hline 312 Support for the creation and development of micro-enterprises & $9,206,549.8$ & 15.6 \\
\hline 313 Encouragement of tourism activities & $3,057,326.7$ & 5.2 \\
\hline 321 Basic services for the economy and rural population & $7,232,685.2$ & 12.3 \\
\hline 322 Village renewal and development & $6,629,139.3$ & 11.2 \\
\hline 323 Conservation and upgrading of the rural heritage & $1,447,188.3$ & 2.5 \\
\hline 331 Training and information of economic actors & $304,774.6$ & 0.5 \\
\hline 421 Inter-territorial and trans-national cooperation & $773,371.5$ & 1.3 \\
\hline $\begin{array}{l}\text { 431-1 Running costs, acquisition of skills and animation - selected } \\
\text { LAGs }\end{array}$ & $6,447,929.4$ & 10.9 \\
\hline $\begin{array}{l}\text { 431-2 Running costs, acquisition of skills and animation - potential } \\
\text { LAGs }\end{array}$ & $4,423,556.3$ & 7.5 \\
\hline Total & $5,8957,797.7$ & 100.0 \\
\hline
\end{tabular}

Source: LDSs of 32 approved strategies.

Data shows the structure of the number of projects to be funded by LDSs and the number of beneficiaries who intend to be supported. The lowest number of planned projects and beneficiaries is planned in the strategies of LAG Razlog - 25 numbers of projects and beneficiaries, and the higher in the LAG Isperih - 100 projects and 150 beneficiaries. In $57 \%$ 
of the surveyed LAGs the number of projects and beneficiaries is between 25 and 45 .

The planned number of projects in the strategies of 23 approved LAG is 877 and the number of beneficiaries is 856 . Similarly of the structure of the distribution of funds under the indicative budget by measures the structure of the number of projects and the number of beneficiaries of the measures (Table 4) the highest share is the number of projects and beneficiaries in measures 121 "Modernization of agricultural holdings", respectively 18.1 and $21.1 \%$ and measure 312 "Support for the creation and development of microenterprises", respectively 18.7 and $19.2 \%$. The lowest priority measure is 122 "Improving the economic value of the forests" covering $0.2 \%$ of the projects and beneficiaries $-1 \%$ of the projects and $1.5 \%$ of the support beneficiaries.

Table 4. Structure of planned in the LDSs projects and beneficiaries

\begin{tabular}{|l|c|c|}
\hline \multicolumn{1}{|c|}{ Measure } & $\begin{array}{c}\text { Structure of } \\
\text { projects }\end{array}$ & $\begin{array}{c}\text { Structure of } \\
\text { beneficiaries }\end{array}$ \\
\hline 111 Training, information and diffusion of knowledge & 4.3 & 3.4 \\
\hline 121 Modernization of agricultural holdings & 18.1 & 21.1 \\
\hline 122 Improving the economic value of the forests & 0.2 & 0.2 \\
\hline 123 Adding value to agricultural and forestry products & 10.4 & 10.3 \\
\hline 122 Improving the economic value of the forests & 1.0 & 1.5 \\
\hline 226 Restoring forestry potential and introducing prevention actions & 1.6 & 1.6 \\
\hline 311 Diversification into non-agricultural activities & 11.2 & 14.0 \\
\hline 312 Support for the creation and development of micro-enterprises & 18.7 & 19.2 \\
\hline 313 Encouragement of tourism activities & 5.1 & 4.8 \\
\hline 321 Basic services for the economy and rural population & 11.7 & 8.8 \\
\hline 322 Village renewal and development & 9.2 & 7.0 \\
\hline 323 Conservation and upgrading of the rural heritage & 6.2 & 6.1 \\
\hline 331 Training and information of economic actors & 2.2 & 2.0 \\
\hline Total & 100.0 & 100.0 \\
\hline
\end{tabular}

Source: LDSs

Differences in the budget set in the LDSs of the surveyed LAGs by measures showed that the amounts vary from 2 to 13 times for different measures and the highest planned budget is in the strategy of LAG High Western Rhodopes and LAG Radomir- Kovachevtsi, which is 2,000,000 euro and it is about 2 times higher than this planned in LDS of LAG Galabovo. The biggest difference in the planned funds is observed for measure 123 "Adding value to agricultural and forestry products" (the amount varies 13 times) and measure 321 - Basic services for the economy and rural population", with a minimum of 11 times less than planned maximum funds in the LDS of LAG Knezha. Less difference between minimum and maximum of planned budged are observed for measure 41.

Data to 01.11 .2013 for the implementation of measure 41 show that only $27.7 \%$ of the applications were approved. Approved expenditures are only $25 \%$ of the expenditures of the applications. This shows that the desire to apply the measure exceeds the funds in it, which could be granted (Table 5). According to estimates of experts at the National rural network resources available to finance applications under Axis 4 LEADER is three times 
less than shown interest for applications. Approved projects by 35 LAGs for verification of State Fund Agriculture (SFA) are 628, and 238 were approved, i.e. about $63 \%$ of applications are not approved. The concluded contracts are 144 worth $446,001,463.8$ euro, which is only $16.58 \%$ of the approved projects by the LAG and $8.38 \%$ of the total budget in measure 41 , which shows that there are differences in the criteria for project approval by the LAG on one hand and SFA on the other. Simultaneously, the late start of the implementation of LDSs created prerequisites LAGs to approve projects that have relatively limited impact on the area and contribute to achieving the objectives of the strategy, which is the reason for the low percentage of projects approved by the State Fund Agriculture.

Table 5. Received and approved applications, contracts under Measure 41 and 431-1

\begin{tabular}{|l|c|c|c|c|c|c|}
\hline \multirow{2}{*}{ Measure } & \multicolumn{2}{|c|}{ Applied Applications } & \multicolumn{2}{|c|}{$\begin{array}{c}\text { Approved } \\
\text { Applications and } \\
\text { Contracts }\end{array}$} & \multicolumn{2}{c|}{ Payments (June, 2014) } \\
\cline { 2 - 6 } & No. & $\begin{array}{c}\text { Total } \\
\text { expenditure, } \\
\text { mIn. EUR }\end{array}$ & No. & $\begin{array}{c}\text { Total } \\
\text { expenditure, } \\
\text { mIn. EUR }\end{array}$ & $\begin{array}{c}\text { Total } \\
\text { expenditure, } \\
\text { mIn. EUR }\end{array}$ & $\begin{array}{c}\text { Percent of } \\
\text { contracts }\end{array}$ \\
\hline $\begin{array}{l}\text { 41 Implementation } \\
\text { of the local } \\
\text { development } \\
\text { strategies }\end{array}$ & 126 & 209 & 35 & 53 & 5.8 & 10.9 \\
\hline $\begin{array}{l}\text { 431-1 Running } \\
\text { costs, acquisition of } \\
\text { skills and animation } \\
\text { - selected LAGs }\end{array}$ & 126 & 23,7 & 35 & 12,4 & 5.3 & 43.3 \\
\hline
\end{tabular}

Source: Information for progress of Rural Development Program (June, 2014)

Despite the great interest and contracts for $98 \%$ of funds under Measure 41 "Implementation of local development strategies" are reached between 63.6 and $71.6 \%$ than targeted in the Rural Development Program (Table 6).

Table 6. Degree of achievement of the reference indicators in RDP M-41 "Implementation of local development strategies"

\begin{tabular}{|l|c|c|c|c|c|}
\hline \multicolumn{1}{|c|}{ Indicator } & Kind & Measure & Target & Result & $\begin{array}{c}\text { Degree of } \\
\text { achievement (\%) }\end{array}$ \\
\hline $\begin{array}{l}\text { Number of supported } \\
\text { LAGs }\end{array}$ & General & Number & 50 & 35 & 70 \\
\hline Total area of the LAG & General & sq.km. & 36,000 & 25,800 & 71.6 \\
\hline $\begin{array}{l}\text { Number of projects } \\
\text { financed by LAGs }\end{array}$ & General & Number & 2,500 & $\begin{array}{c}1,007 \\
\text { May 2014 }\end{array}$ & - \\
\hline $\begin{array}{l}\text { Population in the territory } \\
\text { covered by the LAG }\end{array}$ & General & Number & $1,260,000$ & 801,000 & 63.6 \\
\hline
\end{tabular}

Source: Ministry of Agriculture and food, National Rural Network, 2013. 
These data indicate weaknesses in the allocation of funds in the RDP and limit the population involved in the realization of LDSs.

Discouraging impact on the activity of local communities has insufficient publicity of assessment procedures and approval of projects under Axis 4. From the conducted four procedures for acceptance of projects, on the website of the RDP, only the first call on the measure 431-2 has been published register of the accepted proposals. There are procedures, on which have not been published lists neither on applicants neither on the confirmed projects. There is a lack of information and for the classification of projects through evaluation criteria.

At the same time the realization of the projects are accompanied with a number of problems that according to a survey are:

- The long period of time from the submission of projects to their approval, reaching 9 months in sub measure 431-2 and 15 months in measure 41. According to the respondents this leads to a decrease in interest and decrease the activity of local communities;

- A significant proportion of respondents (47\%) share common difficulties in organizing meetings to inform residents, $53 \%$ of them share the opinion that they had some difficulties in determining the local leaders, but they did not affect the quality of their activities (Table 7). Respondents share common problems associated with disease of speakers who have caused a reordering of the planned activities or deposition over time. In this respect, they shared their negative opinion on the complicated procedure to change the period to implement the various activities involved in the project and the need for information for each activity.

Table 7. Estimates of the representatives of LAG for creation of administrative capacity and problems in creating and implementing of LDSs (in \%)

\begin{tabular}{|l|c|c|c|c|c|}
\hline Indicators and assessments & No difficulties & $\begin{array}{c}\text { Customary } \\
\text { petty } \\
\text { difficulties }\end{array}$ & $\begin{array}{c}\text { Some } \\
\text { difficulties }\end{array}$ & $\begin{array}{c}\text { Significant } \\
\text { difficulties }\end{array}$ & Total \\
\hline $\begin{array}{l}\text { Organization of meeting for } \\
\text { local citizens information }\end{array}$ & 15 & 47 & 15 & 23 & 100 \\
\hline Defining of local leaders & 8 & 23 & 53 & 23 & 100 \\
\hline Training of local leaders & 31 & 31 & 31 & 7 & 100 \\
\hline $\begin{array}{l}\text { Visits to LAG located in other } \\
\text { member states }\end{array}$ & 23 & 61 & 16 & - & 100 \\
\hline $\begin{array}{l}\text { Creation of a local } \\
\text { development strategy }\end{array}$ & 8 & 69 & 23 & 100 \\
\hline $\begin{array}{l}\text { Discussion and adoption of } \\
\text { strategy of local citizens }\end{array}$ & & & 39 & 61 & 100 \\
\hline
\end{tabular}

Source: Doitchinova et al., 2012.

In comparative perspective between these activities - the greatest difficulty was in determining the local leaders and organization of meetings to inform local residents, and two of the groups had significant difficulties, respectively, $23 \%$ of respondents. These 
are communities with a large number of small settlements, where were carrying out joint activities for residents of several villages.

Interesting is the comparison between the respondents' answers to the problems in creating strategies and their acceptance by local communities. Considerably more significant are the difficulties in promoting strategies. Therefore the strategies of $11 \%$ of LAGs were revised with a purpose to reflect more fully the conditions of rural areas.

- Not well developed and constantly changing regulatory framework on the implementation of LEADER in terms of project realization (as 100\% of respondents). This creates uncertainty and discourages potential beneficiaries. Only in the 5 months (September 2013 - January 2014) The Minister of Agriculture and Food has issued three orders to change the rules to implement measures 41 "Implementation of local development strategies" and 431-1 "Management of Local Action Groups, acquiring skills and achievement of social activity of the territory of the local action groups";

- Long delays in the processing of applications for reimbursement, which complicates the process of successful implementation of the sub-measure 431-2. The period of reimbursement for $64 \%$ of respondents LAGs is between 6 and 9 months, and in $14 \%$ - even more than 1 year;

- Insufficient administrative capacity of local level for project management in support of local development activities such as the LEADER approach (according to $71 \%$ of respondents this creates considerable difficulties).

On the issue of assessing the administrative capacity of municipal administration and LAG participants, $52 \%$ of respondents indicate that despite the training of employees in municipal administrations there are only separate competent municipal employees who are responsible for the problems of developing and managing of the projects. At the same time, insufficient administrative capacity is met only in 5\% of cases. In three municipalities (14\%) - the assessment is that employees are sufficiently qualified for developing and managing various projects and in $29 \%$ of them that they need additional training to deal with the work of the LAG.

- Although legally planned limits the influence of public authorities in the management of the LAG is dominant. The reasons are that municipalities have initiated the establishment of LAGs in 71\% of cases, and the scheme of financing projects in measure 431-2 put LAGs financially dependent on the most part of the project.

- Relatively low quality and sustainability of established partnerships at the local level, especially in LAGs covering the territory of two or more municipalities. The survey found out problems in $36 \%$ of the total number of LAGs and $63 \%$ located in the territory of two or more municipalities;

- Low quality on some procedures for implementing LDS adopted by the LAG, aggravated a process of implementation of LDS or need to be amended;

- Staff turnover, causing a partial or even a complete change of the teams working on the implementation of the sub-measure 431-2 and 41. 
Presence of difficulties in the motivation of local community involvement in the initiatives of local partnerships - $48 \%$ of respondents believe that in organized forums participate only interested citizens and representatives of the local administration, and 19\% that are actively participate in the entire territory;

\section{Suggestions for improving the administration of the LEADER approach and increase the activity of the local communities}

The creation of a favourable and stable environment for the LAG is crucial to building local capacity, skills creation and functioning of local action groups, LDSs and their implementation.

To increase the role of the LEADER approach and to improve the regulatory environment for the LAG is necessary to create some prerequisites:

To increase the importance of the LEADER approach in the new rural development program. Its share has to be closer to that of the Czech Republic, Hungary and even Estonia.

$>$ To improve the transparency of procedures for implementing Axis LEADER as a requirement to increase the motivation and activity of local communities.

$>$ to improve coordination between the Ministry of Agriculture and Food, State Fund "Agriculture" and the beneficiaries of the measures of Axis 4 from the RDP.

$>$ Improving coordination and conflict resolution between participants in the projects regarding some of the LEADER initiatives through surveillance and supervision regarding the process of decision-making and operational implementation.

$>$ Implementation of changes in certain procedures related to the implementation of measures and financing of projects.

$>$ Shortening the deadlines for payment of financial assistance under the measure. They currently range between 100 and 129 days (4.5 - 6 months).

$>$ Improvement of local self-government, which is an important factor in mobilizing local communities and rural areas development and for the increase of public participation at local level.

Although during the last decade were implemented a number of initiatives in this direction, public participation at local level is still relatively underdeveloped. A long-term support for the establishment of structures for cooperation in rural development and mobilization of local communities is needed. In this regard, municipalities could be actively involved in initiatives of organizations like the National Association Legal Initiative for Local Government. This would help municipalities to increase their efficiency at work, to improve local services and to lobby more effectively for their interests at national level. Simultaneously, they will gain more experience in terms of improving the capacity of local level to solve various problems of communities.

$>$ Increasing the capacity of local authorities and participants in LAG in order to achieve better implementation of the project cycle and increase 
the knowledge and skills for developing and managing various projects.

$>$ To improve the opportunities for transnational cooperation of LAG on LEADER initiative as well as their participation in a wide range of initiatives linked with an increase of the capacity of groups to exchange information and to share best practices between territories and LAG from different regions is necessary:

$>$ The activity for realization of a "Leader" and for support of LAG to be stimulated and supported by many organizations.

National Network for Rural Development could be useful for LAG by one of the activities set in its Action Plan, namely the initiation of annual or if necessary - with greater frequency - national meetings in which participation can take all citizens, businesses, organizations and institutions related to rural development.

LAG could be supported by the National Rural Network also regarding their awareness as one of the activities of the National Rural Network in Bulgaria is associated with identifying, analysing and providing information on best practices applicable in Bulgaria (on various topics contained in the Community strategic guidelines for Rural Development and the Program for Rural Development - innovation, renewable energy, rural employment). Through it, the LAG can carry out exchanges of experience and knowledge of administrative rules, procedures and enforcement mechanisms within the program for rural areas and to provide expert assistance to conduct training seminars.

Bulgaria as an EU member to be engaged in more initiatives for implementation Discouraging impact on the activity of local communities has insufficient publicity of assessment procedures and approval of projects under Axis 4. From the conducted four procedures for acceptance of projects, on the website of the RDP, only the first call on the measure 431-2 has been published register of the accepted proposals. There are procedures, on which have not been published lists neither on applicants neither on the confirmed projects. There is a lack of information and for the classification of projects through evaluation criteria.

The participation of LAG in our country in initiatives of this kind would contribute to enhancing their capacity for transnational cooperation and inclusion in global networks, promoting the relationship between rural people and rural initiative groups in national and European policies and funds.

\section{Literature}

1. Biderman, A., Kazior, B., Serafin, R., Szmigielski, P. (2004): Building partnership. A practical manual, Polish Environmental Partnership Foundation, Kraków, Poland.

2. Chevalier, P., Maurel, M. (2010): Policy Transfer of the Local Development Model. The Leader Program Implementation in Central European countries, Regional Studies Association, Annual International Conference, May 2010, Pécs, Hungary.

3. Dargan, L. Shucksmith, M. (2008): LEADER and innovation, Sociologia Ruralis, vol. 48, pp. 271-294. 
4. Doitchinova, J., Miteva, A., Stoyanova, Z. (2012): The Process of creating local action group in Bulgaria - problems and prospects, Scientific Annals of the "Alexandru Ioan Cuza” University of Iasi, Economic Sciences Section, Vol. 59, No. 2.

5. Doitchinova, J., Kanchev, I., Miteva, A., Stoyanova, Z., Stanimirova, M., Jecheva, I., Tochkova, E. (2013): Possibilities of LEADER approach for development of viable rural areas and protection of natural recourses, publ. Stopanstvo, Sofia.

6. EC (2013): Rural Development in the European Union, Statistical and Economic Information, Report 2013.

7. Furmankiewicz, M. (2008): Enhancing endogenous development in rural areas: the implementation of the LEADER pilot programme in Poland, Wrocław University of Environmental and Life Sciences, Poland.

8. Gallent, N., Juntti, M., Kidd, S., Shaw, D. (2008): Introduction to Rural Planning, Natural and Built Environment Series, Routledge, London/New York.

9. Gorton, M., Hubbard, C., Hubard, L. (2009): The folly of European Union Policy Transfer: Why the Common Agricultural Policy (CAP) Does not fit Central and Eastern Europe, Regional Studies, vol. 43:10, pp. 1305-1317.

10. Implementation of the Leader approach in Bulgaria. Implementation challenges in Bulgaria in the period 2007-2013 - lessons learned for future programming period, Thematic Group 3, Management Unit of the National Rural Network, 2013.

11. Kjaer, A. M. (2004): Governance, Polity Press, Cambridge.

12. Maurel, C. (2008): Local Development Stakeholders and the European Model. Learning the LEADER Approach in the New Member States, Czech Sociological Review, Vol. 44, no. 3 .

13. Program for rural regions development 2007-2013, Ministry of Agriculture and Food, 2007, Sofia, Bulgaria.

14. Local Partnerships for Rural Development, OECD, 1990.

15. Stoyanova, Z. (2011): Local action groups - problems, possibilities, perspectives, pub. ATL-50, Sofia.

16. Terluin, I. (2003): Differences in economic development in rural regions of advanced countries: an overview and critical analysis of theories, Journal of Rural Studies, vol. 19(3), pp. 327-344. 